\title{
Sodium Selenite Enhanced the Anti-proliferative Effect of MEK-ERK Inhibitor in Thyroid Cancer Cells
}

\author{
JONG BIN KIM, EUN YEOL YANG, JOOHYUN WOO, HYUNGJU KWON, WOOSUNG LIM and BYUNG-IN MOON \\ Department of Surgery, Ewha Womans University School of Medicine, \\ Ewha Womans University Mokdong Hospital, Ewha Womans University, Seoul, Republic of Korea
}

\begin{abstract}
Background/Aim: MEK-ERK pathway plays major roles in the progression of thyroid cancer, while the use of MEK-ERK inhibitors has been limited by its toxicity. We investigated the effect of sodium selenite as an adjunct for MEK-ERK inhibitors to avoid the toxicity of ERK inhibitors. Materials and Methods: TPC1, 8505C and HTori3 cells were treated with U0126 (MEK-ERK inhibitor) and cell viability was counted in the Neubauer chamber. The synergistic effects of sodium selenite and U0126 were also measured. The expression of ERK, $p$-ERK, and $p 90^{R S K}$ was determined by western blot. Results: Treatment with U0126 inhibited proliferation of TPC1 and 8505C cells in a dosedependent manner. When $5 \mu M$ sodium selenite was added to $1 \mu M$ U0126, relative cell survival further decreased. Decreased expression of $p 90^{R S K}$ indicated that sodium selenite down-regulated ERK signaling in thyroid cancer cells. Conclusion: The combination of U0126 and sodium selenite inhibited proliferation of thyroid cancer cells through ERK inhibition.
\end{abstract}

Thyroid cancer is one of the most common cancers in Korea and its incidence has rapidly increased over the past 20 years (1). Thyroid cancer is basically an ERK-driven carcinoma, as up to $75 \%$ of thyroid cancers are caused by mutations that activate the RAS-RAF-MEK-ERK pathway (2). Because of the high dependency of thyroid cancer on ERK activation, various kinase inhibitors of this pathway have been investigated for the effective treatment of thyroid cancer (3). The US Food and Drug Administration recently approved

This article is freely accessible online.

Correspondence to: Hyungju Kwon, MD, Ewha Womans University Medical Center, 1071 Anyangcheon-ro, Yangcheon-Gu, Seoul, 07985, Republic of Korea. Tel: +82 226505025, Fax: +82 226447984, e-mail: hkwon@ewha.ac.kr

Key Words: Selenium, thyroid cancer, MEK-ERK inhibitor, U0126, ERK pathway.
BRAF and MEK inhibitors for the treatment of radioactive iodine-refractory advanced thyroid cancers $(4,5)$. However, therapeutic responses of these inhibitors are only temporary and limited by toxicity in highly proliferative tissues such as skin and the intestinal epithelial barrier.

Selenium has recently gained interest in thyroid cancer (6). Epidemiologic studies have reported that the serum selenium level was lower in patients with thyroid cancer than in healthy controls (7-9). Metere et al. have indicated that selenoprotein expression including glutathione peroxidase and thioredoxin reductase decreased to 50-60\% in thyroid cancer tissues compared with healthy thyroid tissues (10). Decreased serum selenium level was also correlated with higher stage of thyroid cancer (11). On the contrary, selenium supplementation can reduce the inflammatory response of autoimmune thyroiditis, which may decrease the risk of thyroid cancer (12).

The anticancer mechanism of selenium in thyroid cancer, however, has not been fully elucidated $(13,14)$. Previous studies have suggested that the possible mechanism of action of selenite included stimulation of the immune system, activation of natural killer cells, inhibition of angiogenesis, enhancement of damaged DNA fragment repair, and initiation of apoptosis in various cancers (15-19). Recent studies further demonstrated that selenite suppressed cell differentiation through inhibiting ERK activation in vascular smooth muscle cells $(20,21)$. As activation of the RASRAF-MEK-ERK pathway is the major driver of thyroid cancer, sodium selenite may also enhance the growth inhibition of thyroid cancer cells.

We hypothesized that sodium selenite could be administered in combination with ERK inhibitors to avoid their toxicity. The present study investigated the effect of sodium selenite on thyroid cancer cells in combination with a MEK-ERK inhibitor.

\section{Materials and Methods}

Cell culture. Human thyrocyte cell line HTori-3, human papillary thyroid cancer cell line TPC1, and human anaplastic thyroid cancer 
cell line 8505C (Korean Cell Line Bank, Seoul, Republic of Korea) were cultured in Dulbecco's Modified Eagle's Medium (DMEM; Gibco Thermo Fisher Scientific, Waltham, MA, USA), supplemented with $10 \%$ fetal bovine serum (FBS; Gibco Thermo Fisher Scientific). The cells were seeded in Falcon ${ }^{\mathrm{TM}}$ standard tissue culture dishes (BD Biosciences, San Jose, CA, USA), and cultured at $37^{\circ} \mathrm{C}$ in a humidified, $5 \% \mathrm{CO}_{2}$ atmosphere.

Cell viability assay. HTori- 3 , TPC 1 , and $8505 \mathrm{C}$ cells $\left(5 \times 10^{5}\right.$ cells $)$ were seeded in DMEM supplemented with $10 \%$ FBS. Following 24 $\mathrm{h}$ of culturing, the cells were washed twice with phosphate-buffered saline (PBS), and fresh medium was added. The cells were treated with $0.01 \%$ ethanol (CTL) or U0126 (Target Molecule, MA, USA) at a concentration of $1 \mathrm{nM}, 10 \mathrm{nM}, 100 \mathrm{nM}, 1 \mu \mathrm{M}$, or $10 \mu \mathrm{M}$ for $72 \mathrm{~h}$. The cells were also treated with distilled water (CTL) or with sodium selenite (Sigma-Aldrich, St. Louis, MO, USA) at a concentration of $1 \mu \mathrm{M}, 5 \mu \mathrm{M}$, or $10 \mu \mathrm{M}$ for $72 \mathrm{~h}$. To examine the effects of the cotreatment with U0126 and sodium selenite, cells were treated with $1 \mu \mathrm{M}$ U0126, $5 \mu \mathrm{M}$ sodium selenite or with $1 \mu \mathrm{M}$ U0126 plus $5 \mu \mathrm{M}$ sodium selenite for $72 \mathrm{~h}$. Viable cells were counted using a Neubauer chamber. Relative survival rates are shown as the percentages of control viable cells.

Protein expression assay by immunoblotting. Total cell lysates were prepared in $200 \mu \mathrm{l}$ lysis buffer according to the manufacturer's protocol (Cell Signaling Technology, Beverly, MA, USA). Protein concentrations were measured using the Bradford assay with the BioRad Protein Assay kit (Bio-Rad Laboratories, Hercules, CA, USA) according to the manufacturer's directions. Equal amounts of protein were separated by $10 \%$ sodium dodecyl sulfate-polyacrylamide gel electrophoresis (SDS-PAGE; Bio-Rad Laboratories) and electrotransferred onto Hybond ${ }^{\mathrm{TM}}$-ECL nitrocellulose membranes (Amersham Bioscience, Buckinghamshire, UK). Blots of proteins were immuno-labeled with anti-ERK mouse monoclonal antibody, anti-phospho-ERK mouse monoclonal antibody, anti-p90RSK rabbit monoclonal antibody, and anti- $\beta$-actin mouse monoclonal antibody (1:1000, Cell Signaling Technologies, Beverley, MA, USA). Blots were washed with TBST buffer (Tris-buffered saline; $0.2 \%$ Tween 20; Sigma-Aldrich) and incubated for $1 \mathrm{~h}$ at room temperature with peroxidase-conjugated AffiniPure rabbit anti-mouse $\operatorname{IgG}$ (1:2500; Cat No: 315-005-045, Jackson ImmunoResearch Laboratories, West Grove, PA, USA) or peroxidase-conjugated AffiniPure mouse antirabbit IgG (1:2500; Cat No: 211-005-109, Jackson ImmunoResearch Laboratories). Labeled proteins were detected using an enhanced chemiluminescence detection system (Amersham Bioscience). ImageJ program ver 1.8.0 (NIH, USA) was used for quantitation.

Statistical analysis. The statistical significance of the differences between groups was assessed using Student's $t$-test with R 3.4.0 (R Development Core Team, Vienna, Austria). Data are expressed as the mean \pm standard error of the mean (S.E.M.) of at least three independent experiments. $p<0.05$ was considered to indicate a statistically significant difference.

\section{Results}

The effect of MEK-ERK inhibitor (U0126) on cell proliferation. To determine the optimal concentration of ERK signaling inhibition, TPC1 and 8505C cells were treated with $1 \mathrm{nM}, 10 \mathrm{nM}, 100 \mathrm{nM}, 1 \mu \mathrm{M}$, and $10 \mu \mathrm{M}$ U0126. As shown in Figure 1, U0126 reduced viability of both TPC1 and 8505C cells in a dose-dependent manner. Treatment with $1 \mu \mathrm{M}$ U0126 decreased survival of thyroid cancer TPC1 cells to $47 \%$ cells and that of $8505 \mathrm{C}$ cells to $55 \%$ (Figure 2). However, treatment of normal thyroid HTori-3 cells with 10 $\mu \mathrm{M}$ U0126 did not lead to the same reduction in viability as observed in the other two cells lines. These results indicated that ERK inhibition is not crucial for normal thyroid cells, but for thyroid cancer cells. We selected the concentration of 1 $\mu \mathrm{M}$ of $\mathrm{U} 0126$ in the ensuing studies to observe the efficacy of sodium selenite.

The effect of sodium selenite on cell proliferation. To investigate the anti-proliferative effects of sodium selenite on thyroid cells, we treated HTori-3, TPC1, and 8505C cells with $1 \mu \mathrm{M}, 5 \mu \mathrm{M}$, or $10 \mu \mathrm{M}$ of sodium selenite. Treatment with $5 \mu \mathrm{M}$ and $10 \mu \mathrm{M}$ of sodium selenite significantly decreased the viability of HTori-3, TPC 1 , and $8505 \mathrm{C}$ cells (Figure 3 ). We selected the concentration of $5 \mu \mathrm{M}$ of sodium selenite in the ensuing studies to observe the effect of cotreatment with sodium selenite and U0126.

The combination effect of sodium selenite and U0126 MEKERK inhibitor. To observe the combination effect of U0126 and sodium selenite on thyroid cancer cells, TPC1 and 8505C cells were co-treated with $5 \mu \mathrm{M}$ of sodium selenite and $1 \mu \mathrm{M}$ of U0126. The combination treatment led to a reduction in the survival of cells (Figure. 4). These results showed that the combination of U0126 and sodium selenite enhanced the anticancer effect of U0126 in thyroid cancer cells.

Down-regulation of p-ERK expression after sodium selenite treatment. To examine the effect of sodium selenite on ERK signaling, we investigated its effect on the expression of $E R K$, $p-E R K$, and $p 90^{R S K}$. Expression of $p-E R K$ was the most significantly down-regulated in both TPC 1 and $8505 \mathrm{C}$ cancer cells after sodium selenite treatment (Figure 5). Decreased expression of $p 90^{R S K}$ confirmed that sodium selenite downregulated ERK signaling in thyroid cancer cells. These results showed that ERK signaling is involved in the anti-cancer effect of sodium selenite on the growth of thyroid cancer cells.

\section{Discussion}

Selenium is an essential trace element in the human body and is required for maintaining optimal health (22). Selenium participates in numerous physiologic processes including redox homeostasis, inflammatory responses, carbohydrate metabolism, and thyroid hormone regulation (23). A recent meta-analysis indicated that selenium intake decreased the risk of some cancers including esophagus, liver, and pancreas cancers (24). These anticancer activities of selenium compounds can differ depending on its chemical 

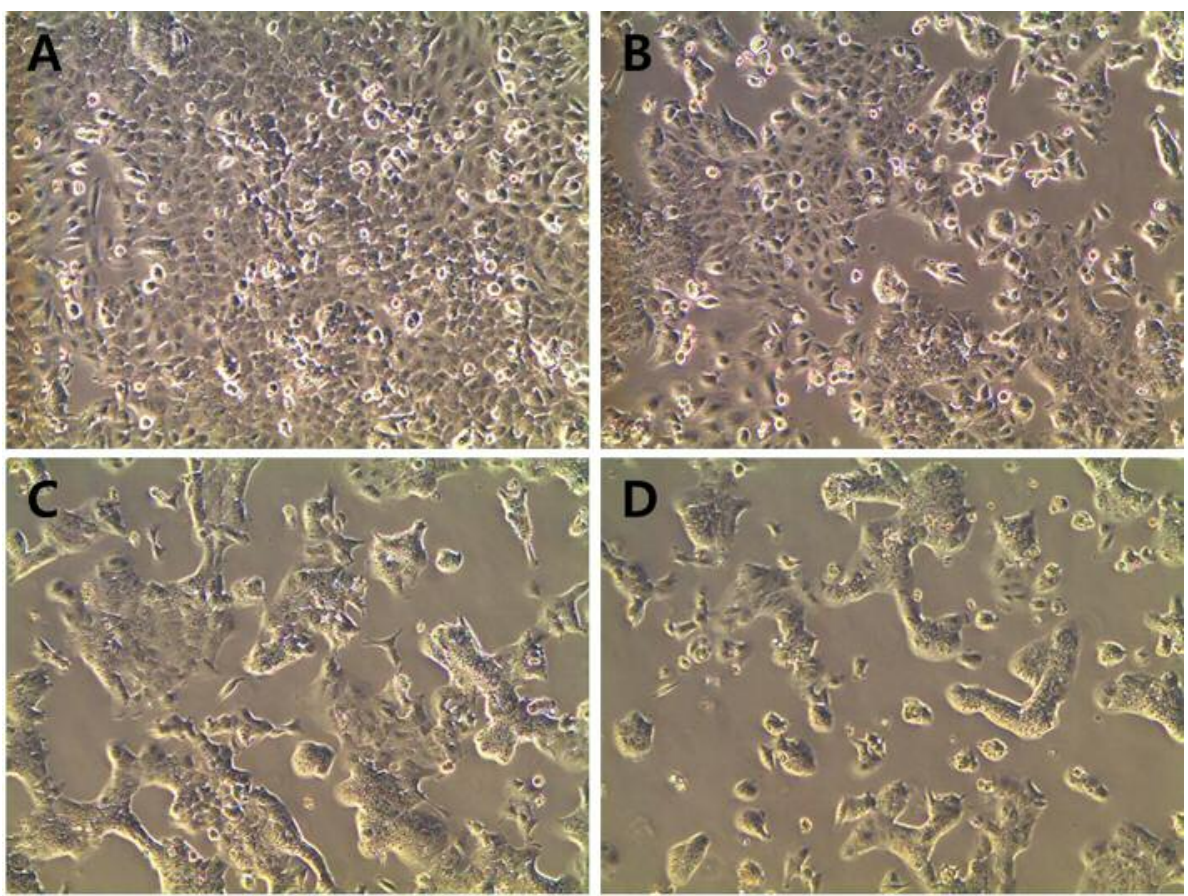

Figure 1. Morphologic changes of 8505C thyroid cancer cells after treatment with A) $10 \mathrm{nM}, \mathrm{B}) 100 \mathrm{nM}, \mathrm{C}) 1 \mu \mathrm{M}$, and D) $10 \mu \mathrm{M} U 0126$ for $72 \mathrm{~h}$.

form, dose, and cancer type (13). Selenium compounds are categorized into three groups: inorganic, organic, and selenium-containing nanoparticles. Of these selenium compounds, inorganic selenite is one of the most redoxactive forms and exhibits high cytotoxic activity (9).

A few previous studies have investigated the mechanism of the effect of selenium in thyroid follicular cells. In one of these, supplementation with sodium selenite enhanced growth and reduced death of normal thyroid cells (25). Modulation of proapoptotic and antiapoptotic mRNA levels was the possible underlying mechanism and high dose of sodium selenite may have further prevented the ER-stress apoptosis. In another study, seleno-methionine supplementation induced cell-cycle arrest in the $\mathrm{S}$ and $\mathrm{G}_{2} / \mathrm{M}$ phase in thyroid cancer cells including ARO, NPA, WRO and FRO cell lines (26). In these cancer cell lines, a time-dependent upregulation of GADD gene families was associated with cancer growth.

We demonstrated that MEK-ERK signaling inhibition by U0126 significantly suppressed the growth of thyroid cancer cells, while it did not significantly affect the growth of normal thyroid cells. It has been shown that U0126 is a specific and noncompetitive inhibitor of both MEK1 and MEK2, and that it suppresses ERK phosphorylation and activation (27). Henderson et al. have demonstrated that concentrations of U0126 higher than $10 \mu \mathrm{M}$ completely blocked ERK phosphorylation and inhibited thyroid cancer cell growth (28). In the present study, treatment with $1 \mu \mathrm{M}$ U0126 for $72 \mathrm{~h}$, reduced relative survival of both TPC1 and $8505 \mathrm{C}$ to $47 \%$ and $55 \%$, respectively. Western blot analysis indicated that $1 \mu \mathrm{M}$ U0126 did not fully suppress ERK expression as expected. Hence, $1 \mu \mathrm{M}$ of U0126 was selected as the treatment dose to examine the synergistic effects of sodium selenite.

Previous studies have indicated that sodium selenite exhibited anti-proliferative activity by modulating various pathways including ERK activation (15-19). Sodium selenite could upregulate ERK expression at lower doses, while at higher doses it decreases ERK activation (27). Our results are also in accordance with these previous studies. We found that treatment with $5 \mu \mathrm{M}$ sodium selenite down-regulated the ERK pathway. Furthermore, the combination of $5 \mu \mathrm{M}$ sodium selenite with $1 \mu \mathrm{M}$ U0126 resulted in a further down-regulation of the ERK pathway in thyroid cancer cells. Decreased expression of $\mathrm{p} 90^{\mathrm{RSK}}$ confirmed that sodium selenite indeed inhibited ERK signaling pathway. These results supported our notion that selenium inhibited thyroid cancer growth and could be used as adjuvant therapy for thyroid cancer.

This study had several limitations. First, the response to U0126 can differ in thyroid cancer cell lines harboring mutations (28). Most thyroid cancers have mutually exclusive single driver mutations. BRAF mutation is found in $60 \%$ of papillary thyroid carcinoma, followed by mutations in the $R A S$ 


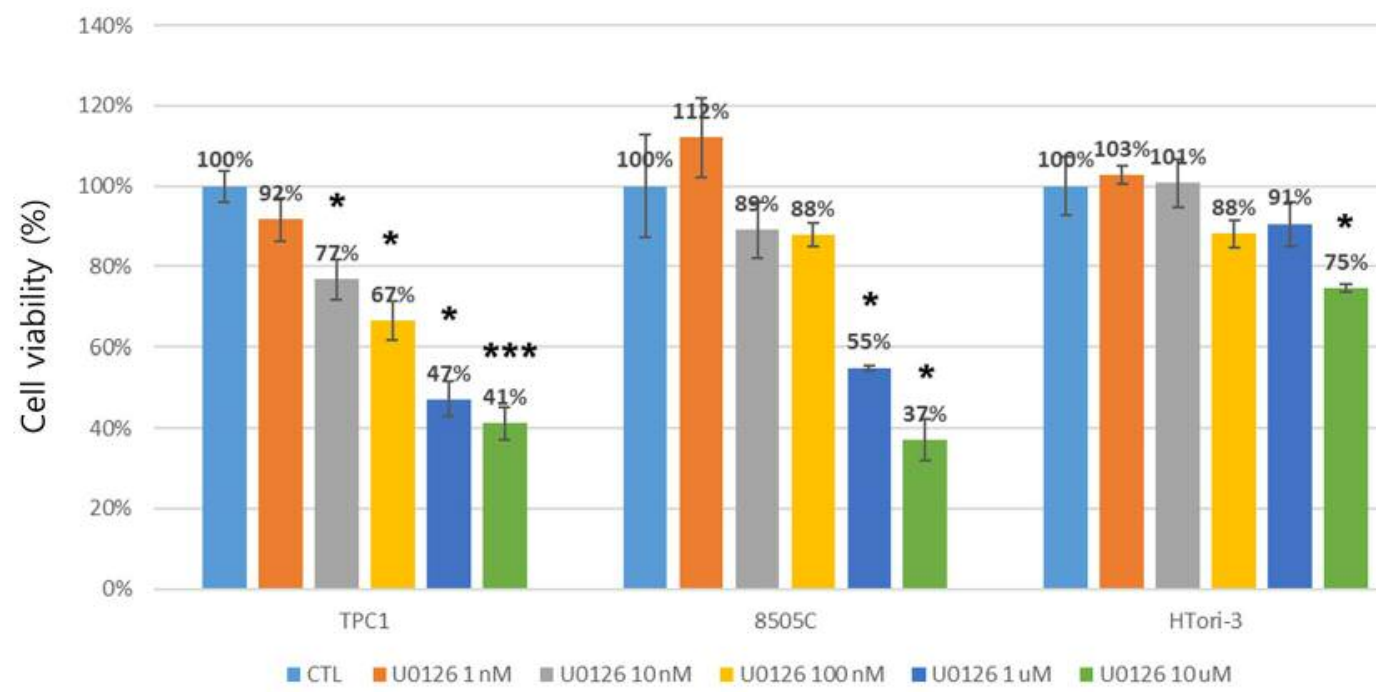

Figure 2. Effect of U0126 treatment on cell proliferation of human thyroid cells. Cells with the RET-PTC1 rearrangement (TPC1), with a BRAF mutation (8505C), or normal human thyroid cells (HTori-3) were treated with $1 \mathrm{nM}, 10 \mathrm{nM}, 100 \mathrm{nM}, 1 \mathrm{uM}$, and $10 \mathrm{uM}$ of U0126 for $72 \mathrm{~h}$. Cells treated with $0.01 \%$ ethanol were used as control cells. Results are presented as mean \pm S.E.M. The results are representative of four independent experiments performed in quadruplet. * and ***represent a significant effect of U0126 as compared to the control at $p<0.05$ and $p<0.001$, respectively.

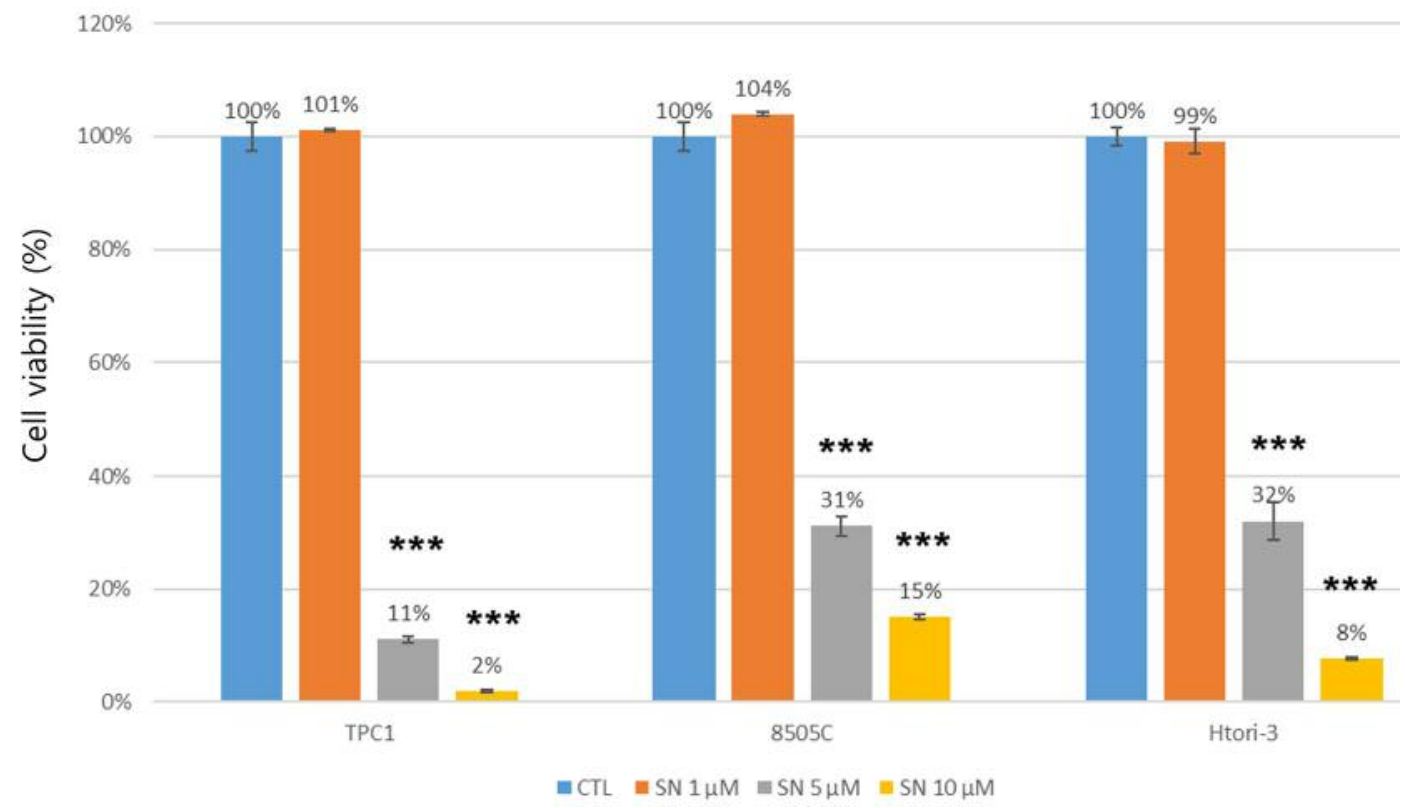

Figure 3. Effect of sodium selenite treatment on cell viability in human thyroid cells. Cells were treated with distilled water (CTL) or with $1 \mu M$, 5 $\mu M$, or $10 \mu M$ of sodium selenite for $72 \mathrm{~h}$. Viable cells were counted in a Neubauer chamber. Results are presented as mean \pm SEM. The results are representative of four independent cultures performed in quadruplet. * and ***represent a significant effect of U0126 as compared to the control at $p<0.05$ and $p<0.001$, respectively.

gene (13\%) (29). In the present study, we used cell lines with the most common mutations including mutations in $B R A F$ and RET/PTC1 rearrangement. Additional studies with cell lines harboring other mutations including RAS mutations are needed. Second, although we demonstrated the additive effect of sodium selenite on MEK inhibitors, these results should be validated in in vivo studies. In conclusion, in the present study, we focused on ERK inhibition by sodium selenite. However, 


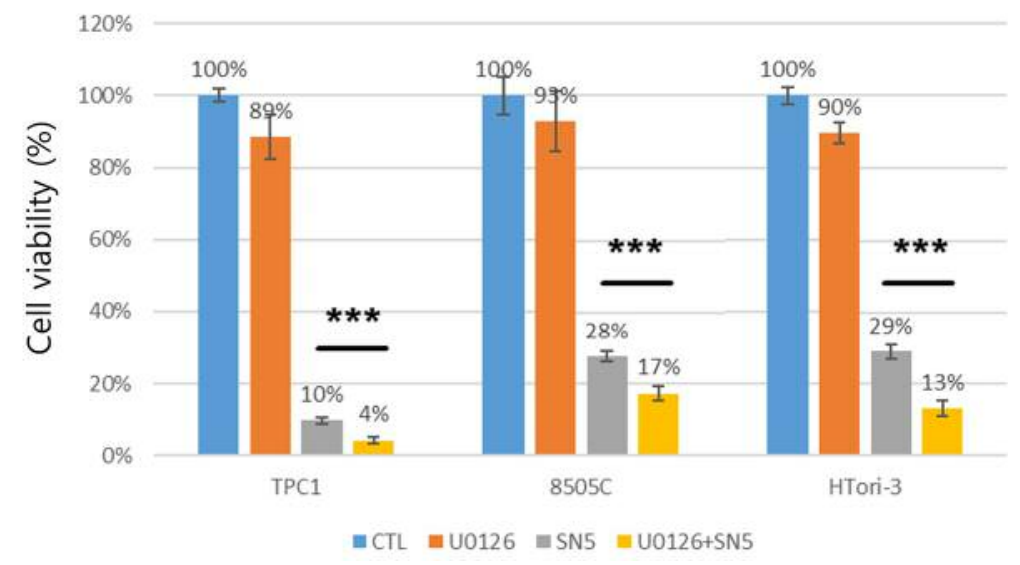

Figure 4. Viability after sodium selenite and MEK-ERK inhibitor (U0126) treatment. Thyroid cells were treated with $0.01 \%$ ethanol (CTL), $1 \mu M$, $5 \mu M$ sodium selenite, or $1 \mu M$ U0126 with $5 \mu M$ sodium selenite for 72 h. Viable cells were counted in a Neubauer chamber. Results are presented as mean \pm S.E.M. The results are representative of four independent cultures performed in quadruplet. ***represent a significant effect of U0126 with $5 \mu M$ sodium selenite as compared to $5 \mu M$ sodium selenite only at $p<0.001$.

\section{TPC1}

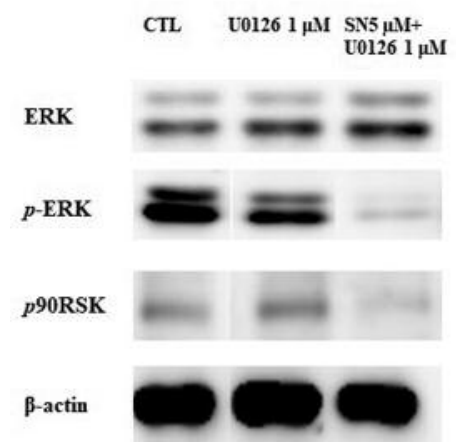

$8505 C$

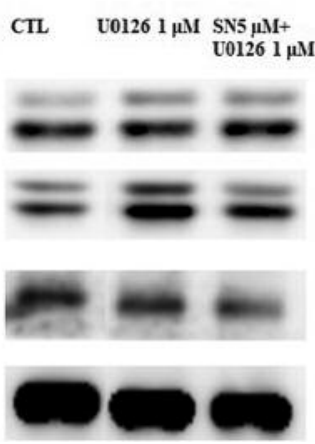

HTori-3

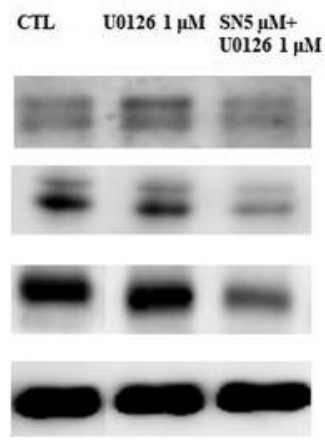

Figure 5. Expression of ERK, $p$-ERK, and p90RSK after sodium selenite treatment for 72 h. A total of $5 \times 10^{5}$ of TPC1, 8505C, and HTori-3 cellss were seeded in DMEM containing $10 \%$ fetal bovine serum. Cell extracts were analyzed by western blot to detected the proteins indicated on the right.

sodium selenite can affect various pathways simultaneously. Therefore, further validation studies are warranted.

\section{Conflicts of Interest}

The Authors declare that they have no conflicts of interest.

\section{Authors' Contributions}

Hyungju Kwon and Joohyun Woo made substantial contributions to conception and study design; Jong Bin Kim and Eun Yeol Yang planned the experiments and performed laboratory work. Woosung Lim and Byung-In Moon analyzed and interpreted the results. Hyungju Kwon and Jong Bin Kim wrote the original manuscript. All Authors provided critical feedback and approved the final manuscript.

\section{Acknowledgements}

This research was supported by Basic Science Research Program through the National Research Foundation of Korea (NRF) funded by the Ministry of Science \& ICT (2017R1C1B5076977) and the Ewha Womans University Research Grant of 2017.

\section{References}

1 Jung KW, Won YJ, Kong HJ and Lee ES; Community of population-based regional cancer, registries: Cancer statistics in Korea: incidence, mortality, survival, and prevalence in 2015. Cancer Res Treat 50: 303-316, 2018. PMID: 29566481. DOI: $10.4143 /$ crt.2018.143

2 Zaballos MA, Acuna-Ruiz A, Morante M, Crespo P and Santisteban P: Regulators of the RAS-ERK pathway as 
therapeutic targets in thyroid cancer. Endocr Relat Cancer, 2019. PMID: 30978703. DOI: 10.1530/ERC-19-0098

3 Valerio L, Pieruzzi L, Giani C, Agate L, Bottici V, Lorusso L, Cappagli V, Puleo L, Matrone A, Viola D, Romei C, Ciampi R, Molinaro E and Elisei R: Targeted therapy in thyroid cancer: state of the art. Clin Oncol (R Coll Radiol) 29: 316-324, 2017. PMID: 28318881. DOI: 10.1016/j.clon.2017.02.009

4 Nagarajah J, Le M, Knauf JA, Ferrandino G, Montero-Conde C, Pillarsetty N, Bolaender A, Irwin C, Krishnamoorthy GP, Saqcena M, Larson SM, Ho AL, Seshan V, Ishii N, Carrasco N, Rosen N, Weber WA and Fagin JA: Sustained ERK inhibition maximizes responses of BrafV600E thyroid cancers to radioiodine. J Clin Invest 126: 4119-4124, 2016. PMID: 27669459. DOI: $10.1172 /$ JCI89067

5 Carneiro RM, Carneiro BA, Agulnik M, Kopp PA and Giles FJ: Targeted therapies in advanced differentiated thyroid cancer. Cancer Treat Rev 41: 690-698, 2015. PMID: 26105190. DOI: 10.1016/j.ctrv.2015.06.002

6 Kipp AP: Selenium in colorectal and differentiated thyroid cancer. Hormones (Athens), 2019. PMID: 31273668. DOI: 10.1007/s42000-019-00118-4

7 Shen F, Cai WS, Li JL, Feng Z, Cao J and Xu B: The association between serum levels of selenium, copper, and magnesium with thyroid cancer: a meta-analysis. Biol Trace Elem Res 167: 225235, 2015. PMID: 25820485. DOI: 10.1007/s12011-015-0304-9

8 Baltaci AK, Dundar TK, Aksoy F and Mogulkoc R: Changes in the serum levels of trace elements before and after the operation in thyroid cancer patients. Biol Trace Elem Res 175: 57-64, 2017. PMID: 27263537. DOI: 10.1007/s12011-016-0768-2

9 Tan HW, Mo HY, Lau ATY and Xu YM: selenium species: current status and potentials in cancer prevention and therapy. Int $\mathrm{J}$ Mol Sci 20: 75, 2018. PMID: 30585189. DOI: 10.3390/ijms20010075

10 Metere A, Frezzotti F, Graves CE, Vergine M, De Luca A, Pietraforte D and Giacomelli L: A possible role for selenoprotein glutathione peroxidase $(\mathrm{GPx} 1)$ and thioredoxin reductases ( $\operatorname{TrxR} 1)$ in thyroid cancer: our experience in thyroid surgery. Cancer Cell Int 18: 7, 2018. PMID: 29371830. DOI: 10.1186/s12935-018-0504-4

11 Jonklaas J, Danielsen M and Wang H: A pilot study of serum selenium, vitamin $\mathrm{D}$, and thyrotropin concentrations in patients with thyroid cancer. Thyroid 23: 1079-1086, 2013. PMID: 23350941. DOI: $10.1089 /$ thy.2012.0548

12 Wichman J, Winther KH, Bonnema SJ and Hegedus L: Selenium supplementation significantly reduces thyroid autoantibody levels in patients with chronic autoimmune thyroiditis: a systematic review and meta-analysis. Thyroid 26: 1681-1692, 2016. PMID: 27702392. DOI: 10.1089/thy.2016.0256

13 Kieliszek M, Lipinski B and Blazejak S: application of sodium selenite in the prevention and treatment of cancers. Cells 6: 39 2017. PMID: 29064404. DOI: 10.3390/cells6040039

14 Lipinski B: Sodium selenite as an anticancer agent. Anticancer Agents Med Chem 17: 658-661, 2017. PMID: 27281365. DOI: $10.2174 / 1871520616666160607011024$

15 Li Z, Meng J, Xu TJ, Qin XY and Zhou XD: Sodium selenite induces apoptosis in colon cancer cells via Bax-dependent mitochondrial pathway. Eur Rev Med Pharmacol Sci 17: 21662171, 2013. PMID: 23893182.

16 Luo H, Yang Y, Duan J, Wu P, Jiang Q and Xu C: PTENregulated $\mathrm{AKT} / \mathrm{FoxO} 3 \mathrm{a} / \mathrm{Bim}$ signaling contributes to reactive oxygen species-mediated apoptosis in selenite-treated colorectal cancer cells. Cell Death Dis 4: e481, 2013. PMID: 23392169. DOI: $10.1038 /$ cddis.2013.3

17 Shi K, Jiang Q, Li Z, Shan L, Li F, An J, Yang Y and Xu C: Sodium selenite alters microtubule assembly and induces apoptosis in vitro and in vivo. J Hematol Oncol 6: 7, 2013. PMID: 23327530. DOI: 10.1186/1756-8722-6-7

18 Gong J and Li L: Sodium selenite inhibits proliferation of gastric cancer cells by inducing SBP1 expression. Tohoku J Exp Med 239: 279-285, 2016. PMID: 27477809. DOI: 10.1620/tjem.239.279

19 Tan X, Liao L, Wan YP, Li MX, Chen SH, Mo WJ, Zhao QL, Huang LF and Zeng GQ: Downregulation of selenium-binding protein 1 is associated with poor prognosis in lung squamous cell carcinoma. World J Surg Oncol 14: 70, 2016. PMID: 26956891. DOI: $10.1186 / \mathrm{s} 12957-016-0832-6$

20 Liu H, Lu Q and Huang K: Selenium suppressed hydrogen peroxide-induced vascular smooth muscle cells calcification through inhibiting oxidative stress and ERK activation. J Cell Biochem 111: 1556-1564, 2010. PMID: 21053344.

21 Liu H, Bian W, Liu S and Huang K: Selenium protects bone marrow stromal cells against hydrogen peroxide-induced inhibition of osteoblastic differentiation by suppressing oxidative stress and ERK signaling pathway. Biol Trace Elem Res 150: 441450, 2012. PMID: 22890880. DOI: 10.1007/s12011-012-9488-4

22 Duntas LH and Benvenga S: Selenium: an element for life. Endocrine 48: 756-775, 2015. PMID: 25519493. DOI: 10.1007/ s12020-014-0477-6

23 Valea A and Georgescu CE: Selenoproteins in human body: focus on thyroid pathophysiology. Hormones (Athens) 17: 183196, 2018. PMID: 29873029. DOI: 10.1007/s42000-018-0033-5

24 Kuria A, Fang X, Li M, Han H, He J, Aaseth JO and Cao Y: Does dietary intake of selenium protect against cancer? A systematic review and meta-analysis of population-based prospective studies. Crit Rev Food Sci Nutr 1-11, 2018. PMID: 30570346. DOI: 10.1080/10408398.2018.1548427

25 Nettore IC, De Nisco E, Desiderio S, Passaro C, Maione L, Negri M, Albano L, Pivonello R, Pivonello C, Portella G, Ungaro P, Colao A and Macchia PE: Selenium supplementation modulates apoptotic processes in thyroid follicular cells. Biofactors 43: 415423, 2017. PMID: 28251705. DOI: 10.1002/biof.1351

26 Kato MA, Finley DJ, Lubitz CC, Zhu B, Moo TA, Loeven MR, Ricci JA, Zarnegar R, Katdare M and Fahey TJ: Selenium decreases thyroid cancer cell growth by increasing expression of GADD153 and GADD34. Nutr Cancer 62: 66-73, 2010. PMID: 20043261. DOI: $10.1080 / 01635580903191569$

27 Han B, Wei W, Hua F, Cao T, Dong H, Yang T, Yang Y, Pan H and $\mathrm{Xu} \mathrm{C}$ : Requirement for ERK activity in sodium seleniteinduced apoptosis of acute promyelocytic leukemia-derived NB4 cells. J Biochem Mol Biol 40: 196-204, 2007. PMID: 17394769.

28 Henderson YC, Fredrick MJ and Clayman GL: Differential responses of human papillary thyroid cancer cell lines carrying the RET/PTC1 rearrangement or a BRAF mutation to MEK1/2 inhibitors. Arch Otolaryngol Head Neck Surg 133: 810-815, 2007. PMID: 17709622. DOI: 10.1001/archotol.133.8.810

29 Cancer Genome Atlas Research N: Integrated genomic characterization of papillary thyroid carcinoma. Cell 159: 676690, 2014. PMID: 25417114. DOI: 10.1016/j.cell.2014.09.050

Received September 25, 2019 Revised October 10, 2019 Accepted October 11, 2019 